\title{
Cultivation of Students' Critical Thinking in Literature Teaching
}

\author{
Shaojun Duan* \\ School of Foreign Languages \\ Kunming University \\ Kunming, China \\ duanshaojun2709@126.com
}

\begin{abstract}
Jane Eyre” is a highly popular novel both in the west and in China and has been adapted for film and TV shows in a number of times. In the eyes of the common people and many scholars, "Jane Eyre" is a work of realistic literature. However, after an analysis of the characteristics of romantic literature and those of realistic literature, we will find that it is difficult to classify the novel into a particular category just on the bas is of the characteristics because this novel owns both features of the two types. In this situation, teachers in literature teaching class can lead students to carry out a debate on the issue, whether "Jane Eyre" belongs to realistic literature or romantic one or both so as to cultivate their critical thinking.
\end{abstract}

Keywords-literature teaching; critical thinking; characteristics of realistic literature; characteristics of romantic literature

\section{INTRODUCTION}

To classify a novel into a certain category, we must hold on the principle of being precise, or chances are that we will make a mistake and classify a work into a wrong category. Like the work "Jane Eyre" by Charlotte Bronte, some may view it as a work of romantic literature while in the eyes of the common people and many scholars; "Jane Eyre" is regarded as a work of realistic literature. In literature teaching class teachers can lead students to carry out a debate on the issue, whether "Jane Eyre" belongs to realistic literature or romantic one or both so as to cultivate their critical thinking. For the sake of reaching this goal, first of all, it is necessary for us to have a general view about realism and romanticism, then, talk about the novel's type by considering the characteristics of realistic literature and those of romantic literature in the next step.

\section{A BRIEF INTRODUCTION TO ROMANTICISM AND REALISM}

In the 18th century, for the guiding function of the Enlightenment, and as literature developing with the development of the society and the development of the industrial culture paving the way, romanticism, or romantic literature, gradually came into the lives of the writers. As a result, romanticism first made its appearance in England as a renewed interest in medieval literature, and the romantic spirit originally came into being and gradually strengthened in Germany, France, and England from the middle of the 18th century. The spirit can mainly be seen in the poetry of William Wordsworth, Samuel Taylor Coleridge, George Gordon Byron,
Charlotte Bronte, Percy Bysshe Shelly, John Keats, and in the prose of Walter Scott and Jane Austen in Britain: In America, the major representatives are Washington Irving, James Fenimore Cooper, William Cullen Bryant, Raoph Waldo Emerson, Nathaniel Hawthorne, Herman Melville, Walt Whitman and Harriet Beecher Stowe.

In $19^{\text {th }}$ century, we first observed the development of the realistic novels, which was the pattern that we often associate with the work of writers such as Austen, Balzac, George Eliot and Tolstoy nowadays. These realistic novels often demonstrate the real life as life itself appears to readers, thus, they incline to avoid the elevated and tragic subject matter, instead they prefer choosing the materials from the commonplace, or the middle or lower classes with their daily struggles as their typical depicting themes. In the next part, we will analyze the problem of which literary form Jane Eyre belongs in reference to the characteristics of romanticism and realism.

\section{CHARACTERISTICS OF REALISTIC LITERATURE}

\section{A. Meaning truth to facts of life}

The definition of realism by Sir P. Harvey can be seen as one of its characteristic. It goes like this, "Realism is a loosely used term meaning truth to the observed facts of life (especially when they are gloomy)."[1]3 From the whole work of Jane Eyre, we can see that many plots of it are fairly gloomy ones, reflecting the gloomy life Charlotte has spent: losing her parents, adopted by her uncle but abused by her aunt and cousins, being sent to the charity school and being a governess in Rochester's mansion[2]149. The most outstanding plot is that when Jane was a little girl, she was usually teased by her brother. No matter when I read this on the book or see this in the movie, I can't hold myself and burst into tears for I compassionate her encounter very much. And this plot is in fact a reflection of part of Bronte's rough childhood. Thus, we can see that Jane Eyre fits this characteristic well. Then, is it a work of realism? Let us go on to see whether it can fit other characteristics or not.

\section{B. Concerned with middle and lower classes' everyday life}

As is known for us that the commonplaces of everyday life among the middle or lower classes are always the concerning materials for realistic writers because the characters' fates are 
decided by the environment on the one hand and on the other hand confined by the social elements. This can be seen as the second characteristic of realistic literature. In the work Jane Eyre, Jane was brought up as an orphan, thus, she is no doubt a representative of lower class in her society. However, many people may doubt that she works and lives in a society formed by men from upper class when she grows up, and even at last, succeeds a large fortune. Against this background, she should be a member of the upper class. I have to say that those who see her as a member of upper class have neglected that she initially works as a personal tutor, which is an important consisting part of the job position of teacher. Even when she has a large fortune, she can only be seen as a new-rich rather than a lord. And as a matter of fact, in Jane's time, new-riches cannot be viewed as part of upper class. She can only be a member of middle class. Thus, in conclusion, she is a representative of both middle and lower classes. Furthermore, the whole story is about Jane's life experiences, this fits well with the words "chiefly concerned with the commonplaces of everyday life among the middle and lower classes".

\section{Critical realism}

The third characteristic of realism is that it not only reflects the reality objectively, concretely and genuinely, but also discloses and criticizes the reality strongly. "The book, a critique of Victorian assumptions about gender and social class, became one of the most successful novels of its era, both critically and commercially."[3]4 In Bronte's works, she usually attacks the greed, petty tyranny and lack of culture among the upper classes and sympathizes with the sufferings of the workers and of poor people. And in her personal representative work Jane Eyre, it is of no doubt that she also does as the above. In the work, when Jane lives in Rochester's family, she lacks cultural activities. The only one filled with the atmosphere of culture is the countless parties among the upperclass members. However, even theses parties are not real parties, for members of upper classes never waste time on things that are of no value to them. So, these parties are actually measures to get messages from others, ways to get to know some big fish, and places to have talks with others on some severe problems that are related to their interests. From this aspect, the author implicitly criticizes the fact that upper class members are in lack of cultural activities. In terms of sympathizing with the sufferings of the workers and of poor people, we can see from other upper-class members' attitudes toward Jane.

\section{Typical character creation under typical circumstance}

The fourth characteristic is that realism creates the typical characters under the typical circumstances. Like Jane, as she grows up in a circumstance full of hardships, she gradually becomes a stubborn woman. And, actually, the hardships in the way of her growth could be seen everywhere at Bronte's time. So, speaking of this characteristic, we can't deny that Jane Eyre also fits well with it.

Jane Eyre, a work of Victorian age, should be a realist novel at first sight. And as all of the four characteristics of realism can be found in the work, can we classify the work as a piece of realistic literature? I would like to say "yes" to answer this question, and this point of view is in fact accepted by most of people, including many scholars. But, so as to be precise, we have to try to find whether there are characteristics of romanticism in the work or not.

\section{CHARACTERISTICS OF ROMANTIC LITERATURE}

\section{A. Neoclassicism opposition}

The romantic literature opposes neoclassicism, which emphasizes formality, order, and authority, romanticism stresses imagination, passion and individuality. Furthermore, romantic literature, for the first time, views the true meaning of the word "imagination" as the most important and significant in literary writing, and advocates individualism since it encourages people to fight for individual rights on the one hand, and to pursue the human happiness boldly on the other hand. "Image" originates from the word "imago" in Latin, and is a certain psychological concept emphasizing the function of seeing in the western culture. However, in romanticism, it is often used to show that the origin of literary creation is not the rational thoughts of people, but something else, particularly the inspiration which does not belong to the concept of rational thinking. [4] In the novel, Jane and Rochester's love affairs are in fact an abolition of the order in Britain at that certain time. In the classical point of view, the love between a noble man and a common people is firmly forbidden, and novels about this can never appear before the eyes of the public, let alone the possibility of its popularity. Besides, in the novel, Jane has been fighting for her own individual rights and human happiness all the time. Like the fight between Jane and her cousin John Reed, it is factually a fight for Jane's happiness. Since Jane was in her aunt's home, she had been teased by her cousin and aunt all the time. Under this circumstance, her fight with her cousin can surely be seen as a battle in which Jane, for the first time, realizes the importance of her own human rights and happiness and fights for them bravely. However, her struggle fails at last, and she is sent to the Lowood School, where she continues to struggle against classicism which neglects her individual rights. And her studying diligently, being a teacher and even changing her teaching position from being the school teacher to being a private teacher in Rochester's home are all struggles to her individual rights and happiness.

In terms of emphasizing the true meaning of imagination, we can also see from the novel "Jane Erye". In above paragraphs, we have already introduced Charlotte's life. And it is by the comparison between her life experiences and the content of the novel that we find several similarities between the novel and Jane Eyre's life experience. Examples are listed here: First, Helen as Jane's bosom friend died of tuberculosis, which helps us remember the writer's two sisters' deaths due to the same disease at home. Second, the male character John Reed drank alcoholism and lived a dissolute life, which is probably modeled upon the writer's brother's life experience before his death since he was also addicted to alcoholism, even worse to opium. Third, Mr. Brocklehurst being a hypocritical religious fervor and the headmaster as well is partly modeled on the image of the Reverend Carus Wilson, who was the Evangelical minister of a church at that time in the writer's 
hometown. Finally, Jane like the author also takes the role of being a governess. Although Charlotte's writing is chiefly based on real life, the story told by the novel has been modified and refined. We can easily see this from the differences between Charlotte's experiences and that of Jane's. In conclusion, the origin and motivation of Charlotte's work comes from her real life while in the writing process, imagination elements are included to modify the story. From here, we can see that in Jane Eyre, the true meaning of imagination, to use one's imagination to modify and perfect a story based on real life, is emphasized.

\section{B. Background of "Long Ago" and "Far Away"}

Another characteristic of romantic literature is that the literary works of romanticism mostly reflects the fantastic and thrilling stories which were always taking place "long ago" or "far away". This can be regarded as a way of escaping from the civilized society. Furthermore, this setting can add mystic and rich color to the works. In the literary works of romanticism we can often see the common people are being praised, the concepts about democratic thinking and humanitarianism are being propagandized, and the idea of loving everything in nature and living a simple life near to nature are also being advocated. We can also find examples in "Jane Eyre" that can meet this characteristic[4].

Firstly, the case of Rochester's former wife in the novel maintains its character of mystery until the story progresses to the very end. Not until near the close of the whole story, we can't find out who the woman in the secret room is and what is the relationship between her and the master of the plantation. Besides, the first appearance of Rochester is also filled with mysterious wind. Secondly, relative to Charlotte's time, the background of the whole novel is surely a "long ago" age. Thirdly, it can be easily seen that the novel is mainly about Jane Eyre, a young orphan raised by Mrs. Reed. And after graduation, she becomes a teacher. These are enough to show that Jane is an ordinary person. And the whole novel is mainly about Jane's struggle with classicism. Thus, the novel is of course a work singing the common or ordinary. As to the concept about democratic thinking and humanitarianism, what's the attitude of the author? To answer this question, I would like to raise another question: why does Jane fight with classicism? That is because she realizes the importance of her individual rights and happiness, which are actually somewhat reflections of democratic thinking and humanitarianism, partly for the main part of democracy is the individual rights. We can see this from the content of the famous "Bill of Rights" in Britain.

\section{Attitude representation}

The third characteristic is that romanticism basically represents an attitude toward the realities of man, nature, and society. It has its sources in the stirring events both in Europe and in America, but it is not an organized system. A saying goes like this: the essence of romanticism is that "literature must reflect all that is spontaneous and unaffected in nature and in man, and be free to follow its own fancy in its own way."[5]1
To discuss the subject of the relationship between Romanticism and nature is a big and wide scope for us. Since the earliest time, Europeans did not in some form or other celebrate nature, but during the period of Romanticism the common attitudes toward nature in the Western world emerged. The Enlightenment had mentions the "natural law" as the source of truth, yet such law was manifested through the civic behavior in the human society. So we can see traditionally Europeans showed little interest in natural landscapes than the Chinese and Japanese did. Paintings of rural settings were usually extremely idealized: either well-tended gardens or tidy versions of the Arcadian myth of ancient Greece and Rome.

Romanticism is rebellious in spirit because it is on the way to react against the neoclassical spirit. On the contrary the romanticists demonstrate deep admiration and love for nature. They think the beauty and perfection of nature can bring them an unspeakable joy and exaltation. Besides, they believe that they are the chosen and favored creatures in nature, thus they have the freedom to eulogize nature by employing his talent.

Next, let us probe into the work Jane Eyre. In this novel; the author has expressed her viewpoint of the true love of human beings. At first, because of the huge differences between Jane and Rochester, it is almost impossible for them to marry each other. However, at the end of the story, Jane married Rochester, which can be seen as a miracle created by true love, for even when Rochester becomes a poor man in economy, the obstacle between him and Jane is still a large one as Jane has succeeded a large fortune. At the very end, Rochester's one eye regained sight. It is another miracle created by love, for even at a time when medical technology is so advanced like today, it is of little chance to help a blind man regain his sight. Thus, the author's point of view toward true love and as well, toward nature, for love is the inner part of nature, may be concluded as true love can create miracles. Why does love belong to the inner part of nature? Because without love, many animals, like man, mandarin duck, and whale and the like, will not be able to multiply offspring.

So, in a word, this characteristic of romanticism can also be found in Jane Eyre.

\section{CONCLUSION}

"Jane Eyre" is a highly popular novel both in the west and in China and has been adapted for film and TV shows in a number of time[6]245. In above analysis, we can clearly see that "Jane Eyre" fits well with both the characteristics of romantic literature and those of realistic literature. So as to the debate on the issue carried out among students whether "Jane Eyre" belongs to realistic literature or romantic one or both, now they have the reasonable answer: it belongs to both. Through this kind of argumentative teaching way, we can also observe that on the one hand, students are more active in participating the learning process, and on the other hand, their critical thinking ability will have a good opportunity to be cultivated or enhanced, compared to the traditional way of teaching. 


\section{REFERENCES}

[1] "Romanticism—Late 18th Century to Mid-19th Century," unpublished.

[2] Realism in Literature," unpublished.

[3] L. Gongzhao, Selected Readings of English Literature. Xi'an: Xi'an Jiangtong University Press, 2009.(in Chinese)

[4] L. Cunbo, Appreciation of British and American Literary Classics. Shanghai: South China University of Technology Press, 2005.(in Chinese)
[5] H. Holman, W. Harmon, A Handbook to Literature. New York: Prentice Hall, 2008.

[6] W. Wenren, History and Anthology of English Literature. Shanghai: Foreign Language Teaching and Researching Press, 1988.

[7] L. Yiqing, L. Jiong, A Brief History of English Literature. Beijing: Foreign Language Teaching and Research Press, 2008. 